\title{
Liquidity Risk and Profitability of Listed Deposit Money Banks in Nigeria
}

\author{
Alalade, Yimka S. (Ph.D) Ogbebor, Peter I. (Ph.D) $\quad$ Akwe, Maxwell (Post-Graduate Student) \\ Department of Finance, Babcock University, Ilishan - Remo, Ogun State Nigeria
}

\begin{abstract}
Illiquidity of firms especially banks can lead to loss of businesses thereby reducing the potentials of earnings and profitability; this is because high liquidity position of a firm helps it to meet with some obligations which lead to funding of loans and advances that could aid banks to earn income in the form of interests on loans. The study examined the effect of liquidity risk on financial performance of listed Deposit Money Banks (DMBs) in Nigeria covering a period of ten years (2009-2018). This study adopted an ex-post facto research design. The population of the study was 15 deposit money banks listed on the Nigerian Stock Exchange and employed panel regression analysis with emphasis on pooled, fixed and random effect models. Secondary data were sourced from the annual reports of the 14 selected quoted banks in Nigeria. The Hausman test was used to justify the appropriate model and inferences were made at 5 percent significant level. The findings revealed that Liquidity risk had significant effects on profitability. In particular, it was established that Liquidity risk indicators had positive and significant effects on individual profitability variables; viz: Return on equity of deposit money banks in Nigeria $(\beta=49.76, p$ $=0.000)$, Return on Assets $(\beta=12.87, p=0.005)$ and Earnings per share $(\beta=20.92, p=0.000)$. The study concluded that Liquidity risk has significant effect on return on equity, return on assets and earning per share of deposit Money Banks listed in Nigeria. The study, therefore, recommended that management of banks should establish strategies to better manage their cash-flows in each product segment and maintain an optimal levels in order to earn higher returns from high volume of idle cash balances.
\end{abstract}

Key words: Earnings per share, Liquidity risk management, Return on assets, Return on equity, Nigeria.

Word Count: 284 words.

DOI: $10.7176 /$ RJFA/11-8-13

Publication date: April $30^{\text {th }} 2020$

\section{Introduction}

A sound and profitable banking sector is in a better position to withstand negative shocks caused by either internal or external factors and contribute to the stability of the financial system. Given the strategic importance of Deposit Money Banks (DMBs) to the economy of every nation, policy makers and regulators have continued to churn out policies that will help improve the overall financial performance of the banking sector.

DMBs perform diverse functions involving households, firms and governments in varying proportions and economic environments that make them susceptible to various categories of risks. Such risks include financial, operational, business and event risks. Traditionally, banks are exposed to financial risks due to the nature of banking business. It is imperative to point out that liquidity risks feature prominently among the risks financial institutions (especially banks due to the nature of incomplete contracts they enter into with depositors) face, although, other risks in this category include credit, market and currency risks. Liquidity risk occurs when a firm fails to meet their financial commitments when they become due (Jenkinson, 2008). This risk may be associated with depositors requesting (withdrawal of) deposits at an ill-timed occasion, stimulating disposal of assets to meet the obligations, thus resulting in losses or even closure of the bank (Crowe, 2009).

Liquidity crisis has significantly affected banks' operational environment. In response to the ruin, regulators and international committees such as the Basel Committee for banking supervision advocated for the active management of liquidity risk. Banks are required to hold a substantial position in liquid assets while trying to be financially stable for them to be sustainable. Despite the increased efficiency in many banks resulting from holding higher positions of liquid assets, financial performance has suffered severely. Liquidity and profitability are inversely related, when liquidity increases profitability decreases and vice versa, hence, the problem in liquidity management is finding a balance between liquidity and profitability. While it is generally agreed that there is a negative relationship between liquidity and bank profitability, there is a counter evidence which shows the need to consider the trade-off between resilience to liquidity shocks and cost of holding less profitable liquid assets as the latter is assumed to impact on the bank's ability to take advantage of opportunities arising in the market which may result in increase in revenue, capital or ability to extend credit, according to Bordeleau and Graham (2010). A liquid financial institution has a smaller portion of its assets in long term loans and a greater proportion of its assets in short term securities that can be quickly liquidated into cash that can then be loaned out, however, a highly liquid bank may mean lack of profitable projects to invest in.

The financial system around the world has undergone significant changes over the last three decades. Banking output, in terms of providing various financial services, can be produced using fewer inputs due to deregulation, 
globalization, financial innovation and technological progress. In other words, technical efficiency can be improved upon significantly in the banking sector. Deposit money banks (DMBs) play a vital role in financial intermediation which leads to greater financial deepening in the economy of today. Financial intermediation is an important role which involves channeling funds from savers to borrowers (Ogbulu \& Eze, 2016).

Deposit money banks need to keep a level of liquidity to be able to play its intermediation role effectively but at a reasonable cost and as such affect profitability positively. Liquidity at a bank is a measure of its ability to readily find the cash it may need to meet demands of depositors/creditors. Liquidity can come from direct cash holdings in currency or on account at the Federal Reserve or the central bank (Elliott, 2014). Ibe (2013) stated that liquidity is a financial term that means the amount of capital that is available for investment. Kumar and Yadav (2013) opined that effective liquidity risk management helps ensure a bank's ability to meet its obligations as they fall due and reduce the probability of an adverse situation developing. Hence, there is need for a strong and sustainable policy on liquidity management techniques by deposit money banks.

Illiquidity of firms especially banks can lead to loss of businesses thereby reducing the potentials of earnings and profitability. This is because high liquidity position of a firm helps it to meet up with obligations some of which may lead to funding of loans and advances that could aid the bank to earn income in the form of interests on loans. Another identified problem is management of liquidity. In the long term, poor liquidity management affects the financial performance of deposit money banks. Deposit money banks try to handle the trade-off between granting loans that cannot be sold quickly at a high price and also issue demand deposits that give depositors the privilege to withdraw funds at any time or at call. Such a mismatch of liquidity, in which a bank's liabilities are more liquid than its assets, causes problems for banks when too many depositors attempt to withdraw at once as it affects bank liquidity position. Poor liquidity planning and implementation can affect the operation of deposit money banks, deposit money banks may be profitable without necessarily being liquid because profitability does not translate to liquidity in all cases and as such liquidity should be managed in order to obtain an ideal level, that is, a level that prevents excess liquidity which may mean lack of business idea by management. At the same time, liquidity levels should not fall below a minimum threshold as it will lead to the inability of the organization to meet short term obligations that are due. This study intends to critically examine the position liquidity risk plays in relation to the profitability of deposit money banks. Therefore, this study will seek to measure the impact of liquidity risk on the financial performance of deposit money banks listed in Nigeria.

\section{Literature review}

\subsection{Concept of profitability}

Profitability measurement is an assessment of an organization's competent use of its assets for its core business processes to generate revenue. To measure a company's overall financial well-being over a specified period or to provide comparisons about similar processes or businesses. Profitability, an indicator of financial performance is one of the principal objectives of deposit money banks. Profitability is vital for a bank to sustain its day to day activities, and for investors to obtain reasonable returns on investment. It is also a key determinant of deposit money banks' financial sustenance as a going concern, hence, investors, analysts and other internal and external stake-holders pay attention to its indicators, however diverse, they may be. Therefore, financial ratios are the easily identifiable and useful tools in measuring profitability. The Return on Equity (ROE), Return on Asset (ROA) and Earnings per share (EPS) are the most widely accepted measures of profitability. García-Herrero et al (2009) supported the use of ROA and ROE as more comprehensive measures of bank profitability since they include operational efficiency and loan loss provision.

Return on Equity is measured as profit before tax/net-worth. It gives the investors opportunity to compare the return on investment with bank deposit rate and other investment returns offered by other businesses. This is because investors are logical and want to invest where they are offered higher rate of returns. Attempts have been made by various researchers to analyze return on investment such as return on capital employed (ROCE) and return on equity (ROE). ROCE is calculated as profit before tax/capital employed. Return on equity is calculated as profit before tax/common stock. The emphasis is that shareholders are more concerned about how much the bank is earning on their equity investment (Edem 2017). Return on equity (ROE) is a measure of profitability that calculates how many units of profit a company generates with each unit of shareholders' equity.

Return on Assets (ROA) is a metric of profitability. ROA is a key proxy frequently used in the literature of bank financial performance. Return on Assets (ROA) is used to measure the effectiveness of the company in generating profits by exploiting its assets, it is also a tool to measure the rate of return on total assets after interest expense and taxes (Heikal, Khaddafi, \& Ummah, 2014). Return on Asset is calculated by dividing net income of the bank by the value of its assets. That is, profit before tax / total assets. ROA is a useful measure of how well a bank manager is utilizing the resources at his/her disposal because it indicates how well a bank's assets are being used to generate profits.

Earnings per Share (EPS) is considered one of the most widely accepted factors to determine share prices and firm value. Individual investors take their individual investment decision based on the EPS. The term - earnings 
per share (EPS) represents the portion of a company's earnings, net of taxes and preferred stock dividends that are allocated to each share of common stock. As good as EPS has been proven to be, it also has its limitation. According to Jensen (2002), the objective of increasing the long term market value of the firm "has its roots in 200 years of research in economics and finance". Value is determined by the magnitude, timing and risk of the future free cash flows of the company. Equity valuation methods use discounted cash flow techniques to estimate the present value of future cash flows in order to determine the value of the shares today. Companies practically pursue the goal of value maximization by investing in projects with returns above the cost of capital, thereby yielding positive net present values (NPVs). EPS can be calculated simply by dividing net income earned in each reporting period by the total number of shares outstanding during the same time frame. Because the number of shares outstanding can fluctuate, a weighted average is typically used. Earnings per share represents the portion of a company's earnings, net of taxes and preferred stock dividends that is allocated to each share of common stock.

\subsubsection{Liquidity}

Liquidity is a financial term which depicts the amount of capital that is available for investment. Bank Liquidity simply means the ability of the bank to maintain enough funds to pay for its maturing obligations. It is the bank's ability to instantly meet cash, cheques, other obligations and legitimate new loan demand while abiding by existing reserve requirements. Nwaezeaku (2008) explained that liquidity is the degree of convertibility to cash or the ease with which any asset can be converted to cash (available for sale at a fair market price).

Liquidity management therefore revolves around the strategic supply or withdrawal from the market or circulation the amount of liquidity in line with a desired level of short-term reserve money without distorting the profit-making ability and operations of the bank. It depends on the daily assessment of the liquidity conditions in the banking system, determining its liquidity needs and thus the volume of liquidity to allot or withdraw from the market. Prudential requirements by regulators is also a key guide to liquidity positions and strategies for managing same. The liquidity needs of the banking system are usually well-defined by the sum of reserve requirements imposed on banks by a monetary authority (CBN, 2012).

Liquidity management is a concept that is getting serious attention all over the world especially with the revolving financial fragility of most institutions and unstable situations of the world economy. Some of the striking corporate goals include the need to increase financial performance and maintain appropriate level of liquidity in order to guarantee safety. The importance of liquidity management as it affects corporate financial performance of deposit money banks cannot be over emphasized. The most important part in managing working capital is required maintenance of its liquidity in daily operation to ensure it meets its obligation (Eljelly, 2004). Liquidity plays a significant role in the successful functioning of a business firm. A firm should ensure that it does not suffer from lack-of or excess liquidity to meet its short-term demands. This study seeks among other things, to investigate the risk of bank liquidity and how it affects bank financial performance.

\subsection{Theoretical Review}

\subsubsection{Shiftability Theory}

The shiftability theory of 1918 propounded by Mouton puts up the shiftability theory which is an extension of the commercial loan theory. The assumption of this theory is based on the proposition that the assets of the bank could either be sold to other lenders or investors or shifted to the central bank. A bank could satisfy its liquidity requirements if it held loans and securities that could be sold in the secondary market prior to maturity. The ability to sell government securities and eligible papers effectively act as substitute for illiquid, longer-term loans with infrequent principal payments. A commercial bank would be able to meet its liquidity needs if it had assets to sell (Crosse \& Hempel, 1980; Santomero, 1984; Tobin \& Brown, 2003).

Waldo (1923) opined that the shift - ability theory is based on the following assumptions

i. Banks should keep themselves in condition to meet the demands of depositors

ii. Short-time loans based upon commercial transactions that will mature and provide funds with which to meet the demands of depositors

The shiftability theory had a profound influence on banking practices by shifting the attention of bankers and banking authorities from loans to investments as a source of liquidity. For example, a bank holding short-term money market instruments such as Treasury bills (TBs) or call loans is in a better position to shift its assets than a bank holding customer notes which could be sold before maturity if necessary.

\subsubsection{The Real Bills Doctrine or Commercial Loan Theory}

According to Yusuf (2015), commercial loan theory assumed that commercial bank liquidity would be assured if assets were held in short-term loans that would be liquidated in the normal course of business. Banks were expected to finance the movement of goods through the successive stages of production to consumption. A support to the commercial loan theory holds that banks should lend only on "short-term, self-liquidating, commercial paper". The theory was postulated to facilitate and finance trade transactions. It is in line with what is called working capital loans or inventory today. Loans should be based on "real" goods as opposed to loans for speculative or purely financial purposes, hence the alternative phrase; the real bills doctrine (Reed \& Gill, 1989; Machiraju, 


\section{8).}

Some notable critics of the theory include, Luckett (1984) who maintained that the theory prohibits the granting of longer-term loans, which are considered illiquid. The basic argument is that the liabilities of a bank are payable on demand and the bank cannot, therefore, meet its obligations if assets are tied up for longer periods of time.

Reed and Gill (1989) also observed that the commercial loan theory failed to consider the needs of the economy.

\subsubsection{Liability Management Theory}

According to Koch and Scott (2008), the liability management theory presents that banks can satisfy their liquidity needs by borrowing in the money and capital markets. According to this theory, banks can meet their liquidity requirements by bidding in the market for additional funds to meet loan demand and deposit withdrawals. When in need of immediate available funds banks can borrow from each other through the interbank market. The liability management theory became increasingly popular as banks gained the ability to pay market rates of interest on large liabilities. The fundamental contribution of the theory was consideration of both sides of a bank's balance sheet as sources of liquidity. Today, banks use both assets and liabilities to meet liquidity needs. Available liquidity sources are identified and compared to expected needs by a bank's Assets and Liability Committee. Management considers all potential deposit outflows and inflows when deciding how to allocate assets and finance operations. Key considerations include maintaining high asset quality and a strong capital base that reduces liquidity needs and improves a bank's access to funds at low cost. This study is anchored on the liability management theory as active liability management moderates the effects of financial risks especially liquidity risks. When liquidity risks are well managed, the negative impacts of risks will be ameliorated, hence, the profitability of such companies will rise.

\subsection{Empirical review}

Bordeleau and Graham (2010) on the impact of liquidity on bank profitability found that profitability is improved for banks that hold some liquid assets, however, there is a point at which holding further liquid assets diminishes a banks' profitability, all else equal. Moreover, empirical evidence from the study by Bordeleau and Graham (2010) also suggested that the relationship between liquidity and bank profitability varies depending on a bank's business model and the state of the economy. Control variables used by Bordeleau and Graham (2010) include quarterly growth in real GDP, unemployment and core inflation, as well as a measure of balance sheet leverage, measured as the ratio of assets to shareholders' equity in the baseline model. Bordeleau and Graham (2010) recommended that policy makers should take cognizance of the trade-off between resilience to liquidity shocks and the cost of holding lower-yielding liquid assets. While holding liquid assets will make banks more resilient to liquidity shocks, thus reducing the negative externalities they might impose on other economic agents, holding too many may impose a significant cost in terms of reduced profitability. Indeed, as retained earnings are the primary means of organic capital generation, low profits may prevent banks from expanding and extending additional credit to the real economy. These benefits and costs are equally applicable both for individual institutions and the financial system.

In the study, liquidity risk, credit risk, market risk and bank capital by Varotto (2011), twelve (12) US bonds with indices spanning different maturities, credit ratings and industry sectors, were used as a sample and the author investigated the impact of the new bank capital regulation for trading portfolios introduced by Basel III. The liquidity risk and credit risk through the so-called incremental risk charge, and the risk of extreme market movements, which was measured with stress tests based on the 2007-2009 financial crisis, were estimated using the new capital requirements. The analysis showed that capital requirements increased substantially more than suggested by extensive impact studies conducted by the regulators with the participation of a large sample of banks. The study suggested that this discrepancy reported by the banks may be due to the assumed risk reduction stemming from their hedging strategies. However, their effectiveness in crisis scenarios remains an open question.

The research study on liquidity risk and performance of the banking system by Kashif, Khan, and Syed (2013) established an empirical relationship between factors of liquidity risk and their effect on the profitability of the banking sector. Secondary data were collected from the income statements, balance sheet and notes of 15 Pakistani banks during 2006-2011. Multiple regressions are applied on data to evaluate the impact of liquidity risk on banks' profitability. The results of multiple regressions show that banks' profitability is affected by liquidity risk significantly. Non-performing loans and liquidity gap are the two factors which exacerbated the liquidity risk and thus creating a negative association with bank's profitability. The researchers emphasized risk management in order to mitigate liquidity risk by having adequate cash assets. This, the authors argued, minimizes the liquidity gap; thus decreasing the dependence on repo market.

Another study by Tabari, Ahmadi, and Emami (2013) found that the variables of bank's size, bank's asset, gross domestic product and inflation will cause to improve the performance of banks while credit risk and liquidity risk will weaken the performance of banks. Panel data related to commercial banks of Iran during the years 2003 
to 2010 were gathered for research. In the estimated research model, two groups of bank-specific variables and macroeconomic variables were used.

Tesfaye (2012) in the study on the determinants of Banks' Liquidity and their Impact on Financial Performance: empirical study on commercial banks in Ethiopia adopted a balanced fixed effect panel regression for the data of a sample of eight commercial banks for the period from 2000 to 2011. Eight factors affecting banks liquidity were selected and analyzed. Results showed that capital adequacy, bank size, share of non-performing loans in the total volume of loans, interest rate margin, inflation rate and short-term interest rate had positive and statistically significant impact on banks liquidity. Real GDP growth rate and loan growth had statistically insignificant impact on banks liquidity. Study recommended further research on the area of factors affecting banks' liquidity in Ethiopia by incorporating regulatory factors and other bank specific and macroeconomic factors.

Maaka (2013) coordinated a research on the relationship between liquidity risk and financial performance of commercial banks in Kenya. Author adopted correlation research design where data was retrieved from the balance sheets, income statements and notes of 33 Kenyan banks during 2008-2012. Multiple regressions were applied to assess the impact of liquidity risk on banks' profitability. Findings of the study showed that profitability of the commercial bank in Kenya is negatively affected due to increase in the liquidity gap and leverage. With a significant liquidity gap, the banks may have to borrow from the repo market even at a higher rate thereby pushing up the cost of banks. The level of customer deposit was also found to positively affect the bank's profitability. The study recommends that banks should periodically monitor their long-term debtors. NPLs show the presence of credit risk, which can rapidly turn into a severe liquidity crisis and banks should open more branches in the country. Since such banks will have established a wide branch network, they will be able to benefit from economies of scale and therefore leading to an improved profitability for the large banks as well.

Siaw (2013) in the study on liquidity risk and bank profitability in Ghana, found that a positive relationship between liquidity risk (both the financing gap ratio and the ratio of net loans to total deposits) and bank profitability measured by the return on assets (ROA) and return on equity (ROE). With an unbalanced data set of 22 banks over a 10-year period spanning 2002 and 2011, the random effects GLS regression based on the Hausman test was used to estimate the determinants of bank liquidity risk. The regression analysis involving the two- stage least squares (2SLS) approach was applied in estimating the effects of liquidity risk on bank profitability. The study employed the financing gap ratio (FGAPR) as the measure of liquidity risk. To ascertain the robustness of the results, the ratio of net loans to total deposits (NLD) as an alternative measure for liquidity risk was also applied. The study recommended that banks in Ghana should strengthen their treasury departments mandated to manage liquidity risk to ensure a sound process for identifying, measuring, monitoring and controlling liquidity risk to maximize the positive risk-return relationship.

Results from the study on returns on investment of deposit money banks (DMBs) in Nigeria by Bosede, Olusegun and Olubukunola (2013) have important implications for the management of banks, policy makers and regulators in Nigeria. The study revealed that apart from credit risk, lending, deposit rates, and investments are associated with large bank size as evident in the network of branches The study recommends that macroeconomic policies that promote low inflation, branch expansion, favorable cash reserves, loan deposit ratios and stable output growth do boost credit expansion and invariably returns and profitability of commercial banks' operations which can thus be enhanced. The authors employed a 3-stage procedure in assessing commercial bank characteristic factors and other macroeconomic variables on total credit, investment, and commercial bank lending and deposit rates. While investigating the relationships between bank efficiency and bank specific factors such as lending rate, deposit rate, liquidity, cash reserve, and inflation and the impact of bank efficiency on those bank level factors as well as financial deepening.

\subsection{Research methodology}

The study covered a population of all deposit money banks in Nigeria. Due to the nature of the study, a sample of fourteen (14) listed banks was drawn from the entire population using purposive sampling technique. The banks include Access Bank, Eco Bank, First Bank, First City Monument Bank, Fidelity Bank, Guaranty Trust Bank, Polaris Bank, Stanbic IBTC, Sterling Bank, Union Bank, United Bank for Africa, Unity Bank, Wema Bank and Zenith Bank. These selected banks are listed on the stock market and this formed the criteria for selection. However, Jaize bank was not considered due to lack of data emanating from its listing on the Nigerian Stock Exchange not too long ago. Data was readily available from published financial statements of listed banks. The scope of the study covered a period of ten years 2009 to 2018 . The research adopted the ex-post facto research design.

\subsection{Model Specification}

The objective of the study is to measure the impact of liquidity risk on profitability of deposit money banks. To achieve this objective, the specified model below is used. Regression model in line with the theoretical framework which relates to the variables are specified as; 


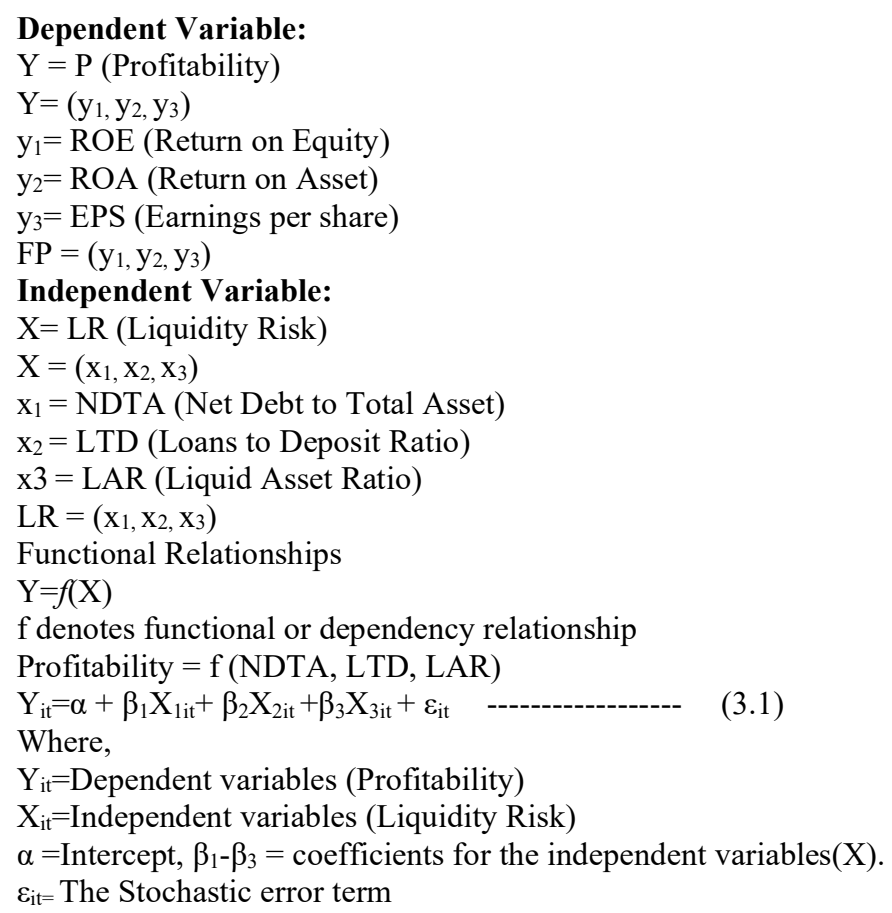

For the purpose of achieving the stated specified objectives of the study, the panel data form of the model is specified as

\section{Model 1}

$\mathrm{ROE}_{\mathrm{it}}=\alpha+\beta_{1} \mathrm{NDTA}_{\mathrm{it}}+\beta_{2} \mathrm{LTD}_{\mathrm{it}}+\beta_{3} \mathrm{LAR}_{\mathrm{it}}+\varepsilon_{\mathrm{it}}$

Where:

$\alpha=$ Constant Coefficient

$\beta_{1}-\beta_{3}=$ Regression coefficients for measuring independent variables

ROE $=$ Return on Equity

NDTA $=$ Net Debt to Total Asset

LTD $=$ Loan to Deposit Ratio

LAR $=$ Liquid Asset Ratio

it $=$ firm year observations

Model 2

$\overline{\mathrm{ROA}_{i t}}=\alpha+\beta_{1} \mathrm{NDTA}_{\mathrm{it}}+\beta_{2} \mathrm{LTD}_{\mathrm{it}}+\beta_{3} \mathrm{LAR}_{\mathrm{it}}+\varepsilon_{\mathrm{it}}-\cdot-\cdot-\cdot-\cdot-\cdot-\cdot-----\mathrm{t}$

Where:

$\alpha=$ Constant Coefficient

$\beta_{1}-\beta_{3}=$ Regression coefficients for measuring independent variables

ROA=Return on Asset

NDTA $=$ Net Debt to Total Asset

LTD $=$ Loan to Deposit Ratio

LAR $=$ Liquid Asset Ratio

it $=$ firm year observations.

Model 3

$\mathrm{EPS}_{\mathrm{it}}=\alpha+\beta_{1} \mathrm{NDTA}_{\mathrm{it}}+\beta_{2} \mathrm{LTD}_{\mathrm{it}}+\beta_{3} \mathrm{LAR}_{\mathrm{it}}+\varepsilon_{\mathrm{it}}$

Where:

$\alpha=$ Constant Coefficient

$\beta_{1}-\beta_{3}=$ Regression coefficients for measuring independent variables

EPS $=$ Earnings per Share

NDTA $=$ Net Debt to Total Asset

LTD=Loan to Deposit Ratio

LAR=Liquid Asset Ratio

it $=$ firm year observations. 


\subsection{Data analysis and discussion of findings}

\subsubsection{DESCRIPTIVE STATISTICS - PERFORMANCE INDICATORS (DEPENDENT VARIABLES)}

As stated earlier, this subsection particularly focused on the description of the variables that are considered as dependent variables in the subsequent analysis. The dependent variables are Return on Equity (ROE), Return on Asset (ROA) and Earnings per Share (EPS).

4.1.1 Descriptive Statistics - Indicators (Dependent Variables)

\begin{tabular}{l|ccccc} 
Variable & Obs & Mean & Std. Dev. & Min & Max \\
\hline ROE & 140 & 0.088 & 0.209 & -0.920 & 1.091 \\
ROA & 140 & 0.011 & 0.029 & -0.182 & 0.106 \\
EPS & 140 & 1.008 & 2.841 & -20.810 & 8.300 \\
\hline
\end{tabular}

Source: Author's Computation, 2020.

Return on Equity (ROE)

As in Table 4.1.1, the average value of return on equity (ROE) is 0.088 . This implies that the average ROE of the banks during the period of this study was $8.0 \%$. The implication of this is that the banks were able to generate about $8 \%$ profit from the shareholders' investment during the period. Overall, this is generally good for the banks. Looking more closely at the results, the minimum return on shareholders' equity was -0.920 while the maximum was 1.091. These mean that some of the banks have faced losses during the years while some recorded profits, though the average performance was reasonable.

Return on Asset (ROA)

As in Table Table 4.1.1 ROA shows a minimum value of -0.182 and a maximum value of 0.106 . These showed that the least performance ratio based on ROA recorded by the banks during the year was about $18.2 \%$ while the largest stood at $10.6 \%$. In other words, some of the banks have faced losses during the years while some recorded profits. Moreover, the average value of Return on Asset (ROA) stood at 0.011 . This suggested that the banks were able to generate about $1.1 \%$ profit from their assets during the period. This is generally attractive.

\section{Earnings per Share (EPS)}

From Table 4.1.1, the average Earnings per Share (EPS) recorded by the banks during the period under study was 1.01. This meant that the banks were able to make about 100kobo for each share of their stock. Alternatively, it meant that the amount of equity earnings attributable to a unit of ordinary shares in issue is generally attractive. Furthermore, the performance indicator has a minimum value of -20.81 and a maximum value of 8.30. These figures depicted that during the year the highest Earnings per Share (EPS) recorded was about N8.30 while the loss was $-\mathrm{N} 20.81$ with a standard deviation of 2.841 .

\subsubsection{Descriptive Statistics - Indicators (Independent Variables)}

Again, this subsection is particularly focusing on the description of the variables that were considered as independent variables in the subsequent analysis. The independent variables are Net Debt to Total Asset (NDTA), Loan to Deposit Ratio (LTD) and Liquid Asset Ratio (LAR).

\begin{tabular}{l|ccccc} 
4.1.2 Descriptive Statistics - Liquidity Risk Indicators & (Independent Variables) \\
Variable & Obs & Mean & Std. Dev. & Min & Max \\
\hline NDTA & 140 & 0.427 & 0.114 & 0.057 & 1.035 \\
LTD & 140 & 0.642 & 0.176 & 0.036 & 1.064 \\
LAR & 140 & 0.251 & 0.141 & 0.016 & 0.707 \\
\hline
\end{tabular}

Source: Authors' Computation, 2020.

Net Debt to Total Asset (NDTA)

In Table 4.1.2, the computed average Net Debt to Total Asset (NDTA) ratio for the entire bank during the years under study was 0.427 . This indicated that on average, about $42.7 \%$ of Total Assets of the banks were tied up in loans. Going by these results, about $57.3 \%$ of the banks' assets did not earn any revenue. Furthermore, the largest and smallest portion of the banks' Total Assets tied up in loans were about 5.7\% while the highest stood at $103.5 \%$. Liquid Asset Ratio (LAR)

The summary Table (Table 4.1.2) shows that there is a variation in liquid asset ratio across the banks during the period under study as evident in the standard deviation value of 0.141 . These ranged from 0.016 to 0.707 . It implied that the ratio reached an all-time high of $70.7 \%$ during the period of this study. However, the average LAR as calculated for the banks was 0.251 which indicated that the banks were liquid on average and has better coverage of outstanding debt. 


\subsubsection{Correlation Matrix}

This subsection focuses on the results of the correlation analysis that showed the degree of associations among the selected variables in this study. The correlation result which related Return on Equity (ROE), Return on Asset (ROA), Earnings per Share (EPS), Net Debt to Total Asset (NDTA), Loan to Deposit Ratio (LTD) and Liquid Asset Ratio (LAR) with each other is discussed. This was carried out to determine whether there were bivariate relationship between each pair of the dependent and independent variables considered in the successive analysis and to ensure that the associations among the explanatory variables were not so high to the point of causing multicollinearity problems.

\begin{tabular}{|c|c|c|c|c|c|c|c|c|}
\hline & $\begin{array}{l}\text { ROE } \\
\text { (1) }\end{array}$ & $\begin{array}{l}\text { ROA } \\
\text { (2) }\end{array}$ & $\begin{array}{l}\text { EPS } \\
\text { (3) }\end{array}$ & $\begin{array}{c}\text { NDTA } \\
(4)\end{array}$ & $\begin{array}{l}\text { LTD } \\
(5)\end{array}$ & $\begin{array}{c}\text { LAR } \\
(6)\end{array}$ & VIF & $1 / \mathrm{VIF}$ \\
\hline ROE & 1 & & & & & & & \\
\hline ROA & 0.232 & 1 & & & & & & \\
\hline EPS & 0.040 & 0.821 & 1 & & & & & \\
\hline NDTA & 0.093 & 0.149 & 0.089 & 1 & & & 2.61 & 0.383 \\
\hline LTD & 0.123 & 0.243 & 0.158 & 0.674 & 1 & & 2.61 & 0.384 \\
\hline LAR & 0.240 & 0.264 & 0.267 & 0.033 & -0.009 & 1 & 1.00 & 0.996 \\
\hline
\end{tabular}

Source: Authors' Computation, 2020.

From the result in columns (1) to (3) of Table 4.1.3, the correlation coefficients among the dependent and independent variables take values between 0.040 and 0.821 . Specifically, in column (1) of the Table; all the correlation coefficients were positives. This meant that Return on Asset (ROA), Earnings per Share (EPS), Net Debt to Total Asset (NDTA), Loan to Deposit Ratio (LTD) and Liquid Asset Ratio (LAR) have positive associations with Return on Equity (ROE). Similarly, in column (2), all the coefficients were positive. This meant that Earnings per Share (EPS), Net Debt to Total Asset (NDTA), Loan to Deposit Ratio (LTD) and Liquid Asset Ratio (LAR) have positive associations with Return on Asset (ROA). In column (3), Net Debt to Total Asset (NDTA), Loan to Deposit Ratio (LTD) and Liquid Asset Ratio (LAR) were the variables that exhibited positive associations with Earnings per Share (EPS).

Moving to the results in columns (4) to (6), the associations among the explanatory (independent variables) ranged from 0.009 to 0.674 in an absolute term. Among the correlation coefficients, 0.674 appears to be the highest while 0.009 was the least. However, according to O'brien, (2007), any coefficient that is less than 0.75 does not suggest problem of multicollinearity. Moreover, none of the VIF values was up to 0.5 confirming that multicollinearity does not exist among the variables.

4.2.1 Test of Hypotheses One

Research Hypothesis (Ho1): Liquidity risk has no significant effect on return on equity of Deposit Money Banks listed in Nigeria 
Table 4.2.1: Regression Result for Return on Equity

\begin{tabular}{|c|c|c|c|c|}
\hline \\
\hline \multirow{3}{*}{ Variable } & \multicolumn{4}{|c|}{ Random-effects GLS regression with Driscoll-Kraay standard errors } \\
\hline & \multicolumn{4}{|c|}{ ROE is the Dependent Variable } \\
\hline & Coeff. & $\begin{array}{c}\text { Drisc/Kraay Std. } \\
\text { Err. }\end{array}$ & t-Stat. & Prob. \\
\hline NDTA & -0.061 & 0.089 & -0.690 & 0.508 \\
\hline LTD & $0.180 * *$ & 0.079 & 2.280 & 0.049 \\
\hline LAR & $0.360 * * *$ & 0.066 & 5.440 & 0.000 \\
\hline cons & -0.091 & 0.087 & -1.040 & 0.324 \\
\hline Model Fitness Test & \multicolumn{4}{|c|}{ F-Stat $/$ Wald $(P$-value $)=49.76(0.000) ;$ Adj. $\boldsymbol{R}^{2}=0.053$} \\
\hline \multirow{2}{*}{ Model Selection Tests } & \multicolumn{4}{|c|}{ Hausman Test $(\boldsymbol{P}$-value $)=1.50(0.683)$} \\
\hline & \multicolumn{4}{|c|}{ LM Test $(P$-value $)=4.52(0.017)$} \\
\hline \multirow{3}{*}{ Post-Estimation Tests } & \multicolumn{4}{|c|}{ PCD test $(P$-value $)=6.333(0.000)$} \\
\hline & \multicolumn{4}{|c|}{ Heteroskedasticity Test $(\boldsymbol{P}$-value $)=93.24(0.000)$} \\
\hline & \multicolumn{4}{|c|}{ Serial-Auto Correlation Test $(\boldsymbol{P}$-value $)=1.763(0.2071)$} \\
\hline
\end{tabular}

Source: Authors' Computation, 2020. Note: ***, ** represent $1 \%$ and $5 \%$ levels of significance.

Model Selection: Hausman Tests and Breusch and Pagan LM Test

From the result in Table 4.2.1 the insignificance of Hausman test result at 5\% level of significant test $(\mathrm{p}-\mathrm{value})=$ 1.50 (0.683) favoured Random Effect (RE) estimators. This means that the appropriate model for investigating the effect of liquidity risk on financial performance (based on Return on Equity) of Deposit Money Banks listed in Nigeria is the Random Effect (RE) model. Furthermore, the Breusch and Pagan LM Test result further strengthened the decision to use RE model and confirmed that the RE model is ideal in this subsection since the LM Test (Pvalue $)=4.52(0.017)$ is significant (Panel effect existed) .

Heteroskedasticity Test, Serial Autocorrelation Test and Cross Sectional Dependence Test

Pesaran CD test statistic results in Table 4.2.1 checked whether the estimated model has cross sectional dependence problem or not when examining the effect of Net Debt to Total Asset (NDTA), Loan to Deposit Ratio (LTD) and Liquid Asset Ratio (LAR) on Return on Equity (ROE). As in the Table, the PCD test value is statistically significant PCD test $(\mathrm{P}$-value $)=6.333(0.000)$. This strongly suggested that the null hypothesis of no problem of cross sectional dependence in the model should be rejected, thus, it was concluded that the model is not free form cross sectional dependence problem. Furthermore, the test statistic values for heteroskedasticity test Heteroskedasticity Test $(\mathrm{P}$-value $)=93.24(0.000)$ is statistically significant at $5 \%$ level. This suggested that the null hypothesis of homoscedasticity should be rejected. For these reasons, the study used Random-effects GLS regression with Driscoll-Kraay standard errors that is robust with the possibility of cross sectional dependence and heteroskedasticity problems. Conversely, the serial autocorrelation test carried out to check whether the relationship between the residual of the models and its lagged version over various time intervals correlated showed an insignificant Serial-Auto Correlation Test (P-value) = 1.763 (0.2071) which indicated the absence of first order autocorrelation among the series in the model.

The estimated fixed effect model is as follows:

$$
\begin{aligned}
& \mathrm{ROE}_{1 \mathrm{t}}=\beta_{0}+\beta_{1} \mathrm{NDTA}_{1 \mathrm{t}}+\beta_{2} \mathrm{LTD}_{1 \mathrm{t}}+\beta_{\mathrm{s}} \mathrm{LAR}_{\mathrm{it}}+\mathrm{s}_{\mathrm{it}} \\
& \mathrm{ROE}_{\mathrm{it}}=-0.091-0.061+\mathrm{NDTA}_{\mathrm{it}}+0.180 * \mathrm{LTD}_{\mathrm{it}}+0.360 * \mathrm{LAR}_{\mathrm{it}}+\varepsilon_{\mathrm{it}} \\
& \text { Interpretation }
\end{aligned}
$$

In Table 4.2.1, the significant value of F-Stat/ Wald (P-value) $=49.76(0.000)$ is an indication that the chosen Random Effect model was statistically significant and at the same time, the joint effect of liquidity risks proxies 
(Net Debt to Total Asset (NDTA), Loan to Deposit Ratio (LTD) and Liquid Asset Ratio (LAR)) on Return on Equity (ROE) is statistically significant at $5 \%$ level of significance. Also, the coefficient of multiple determinations Adj. $R^{2}=0.053$ further confirmed the fitness of the model. The Adjusted R-square value showed that the explanatory variables jointly accounted for about $5.3 \%$ of variation in the Return on Equity.

Looking at the coefficient of Net Debt to Total Asset (NDTA), the result showed that the coefficient is negative and statistically insignificant at $5 \%$ level of significance (coeff. $=-0.061 ; \mathrm{p}-$ value $=0.508$ ). This means that the effect of Net Debt to Total Asset (NDTA) on the performance (based on Return on Equity) of Deposit Money Banks in Nigeria during the period of this study is negative and insignificant. Nevertheless, it can be seen that that the coefficient of Loan to Deposit Ratio (LTD) is positive and statistically significant at $5 \%$ level (coeff. $=0.180 ; \mathrm{p}-$ value $=0.0490$. In other words, it suggests that Loan to Deposit Ratio (LTD) has positive and significant effect on the performance (based on Return on Equity) of Deposit Money Banks listed in Nigeria. Also, this implied that a unit increase in Loan to Deposit Ratio (LTD) of the selected banks listed Nigeria during the period of this study caused about 0.180 units increase in Return on Equity (ROE) of the banks. Just as Loan to Deposit Ratio (LTD), the effect of Liquid Asset Ratio (LAR) is seen to be positive and statistically significant at $1 \%$ level (coeff. $=0.180 ; p-$ value $=0.049)$. This meant that Liquid Asset Ratio $($ LAR $)$ has positive and significant effect on the performance (based on Return on Equity) of Deposit Money Banks listed in Nigeria. Besides, the significant result suggests that Return on Equity (ROE) of the Deposit Money Banks listed in Nigeria during the period of this study increased by 0.360 units given a unit increase in Liquid Asset Ratio (LAR).

Decision: Based on the result of the regression analysis, the statistical evidence from F-Stat/ Wald (P-value) $=49.76(0.000)$; Adj. $\mathrm{R}^{2}=0.053$ established support for the rejection of the null hypothesis $\left(\mathrm{H}_{01}\right)$ which states that Liquidity risk has no significant effect on return on equity of Deposit Money Banks listed in Nigeria. Accordingly, the study concluded that Liquidity risk has significant effect on return on equity of Deposit Money Banks listed in Nigeria.

4.2.2 Test of Hypothesis Two

Research Hypothesis ( $\left.\mathbf{H}_{\mathbf{0} 2}\right)$ : Liquidity risk has no significant effect on return on asset of Deposit Money Banks listed in Nigeria.

Table 4.2.2: Regression Result for Return on Asset

\begin{tabular}{|c|c|c|c|c|}
\hline \multirow{3}{*}{ Variable } & \multicolumn{4}{|c|}{ Random-effects GLS regression with Driscoll-Kraay standard errors } \\
\hline & \multicolumn{4}{|c|}{ ROA is the Dependent Variable } \\
\hline & Coeff. & $\begin{array}{c}\text { Drisc/Kraay Std. } \\
\text { Err. }\end{array}$ & t-Stat. & Prob. \\
\hline NDTA & -0.036 & 0.028 & -1.300 & 0.226 \\
\hline LTD & $0.057 * *$ & 0.021 & 2.760 & 0.022 \\
\hline LAR & $0.052 * *$ & 0.016 & 3.240 & 0.010 \\
\hline cons & -0.024 & 0.013 & -1.820 & 0.102 \\
\hline Model Fitness Test & \multicolumn{4}{|c|}{ F-Stat $/$ Wald $(\boldsymbol{P}$-value $)=12.87(0.005) ; \boldsymbol{A d j .} \boldsymbol{R}^{2}=0.118$} \\
\hline \multirow{2}{*}{ Panel Effect Tests } & \multicolumn{4}{|c|}{ Hausman Test (P-value) $=4.65(0.200)$} \\
\hline & \multicolumn{4}{|c|}{ LM Test $(P$-value $)=3.68(0.028)$} \\
\hline \multirow{3}{*}{ Post-Estimation Tests } & \multicolumn{4}{|c|}{ PCD test $($ P-value $)=10.339(0.000)$} \\
\hline & \multicolumn{4}{|c|}{ Heteroskedasticity Test $=93.30(0.000)$} \\
\hline & \multicolumn{4}{|c|}{ Serial-Auto Correlation Test $($ P-value $)=1.543(0.546)$} \\
\hline
\end{tabular}

Source: Authors' Computation, 2020. Note: $* * *, * *$ represent $1 \%$ and $5 \%$ levels of significance.

Model Selection: Hausman Tests and Breusch and Pagan LM Test

In Table 4.2.2 the Hausman Test $(\mathrm{P}$-value $)=4.65$ (0.200) appears to be insignificant at 5\% level of significance. This supports the Random Effect (RE) estimators. This makes the Random Effect model a suitable model for investigating the effect of liquidity risk on financial performance (based on Return on Asset) of Deposit Money Banks listed in Nigeria. Additionally, the Breusch and Pagan LM Test result further strengthened the decision to use RE model and confirms that the RE model is good in this subsection since the LM Test $(\mathrm{P}$-value $)=3.68$ (0.028) is significant (Panel effect exists) at 5\% level.

Heteroskedasticity Test, Serial Autocorrelation Test and Cross Sectional Dependence (CD) Test

Pesaran CD test statistic results in Table 4.2.2 checks whether the estimated model has cross sectional dependence problem or not when examining the effect of Net Debt to Total Asset (NDTA), Loan to Deposit Ratio (LTD) and Liquid Asset Ratio (LAR) on Return on Asset (ROA). As in the Table, the PCD test value is statistically significant PCD test $(\mathrm{P}$-value $)=10.339(0.000)$. This recommends that the null hypothesis of no problem of cross sectional dependence in the model should be rejected, thus, there is conclusion that the model is not free form cross sectional 
dependence problem. Likewise, the test statistic values for heteroskedasticity test Heteroskedasticity Test $=93.30$ $(0.000)$ is statistically significant at $5 \%$ level. This recommends that the study the null hypothesis of homoscedasticity should be rejected. For these reasons, the study used Random-effects GLS regression with Driscoll-Kraay standard errors that is robust to the possibility of cross sectional dependence and heteroskedasticity problems. On the contrary, the serial autocorrelation test carried out to check whether the relationship between the residual of the models and its lagged version over various time intervals correlate, shows an insignificant Serial-Auto Correlation Test $(\mathrm{P}$-value $)=1.543(0.546)$ which indicates the absence of first order autocorrelation among the series in the model.

The estimated fixed effect model is stated as follows:

$$
\begin{aligned}
& \mathrm{ROA}_{\mathrm{it}}=\beta_{0}+\beta_{1} \mathrm{NDTA}_{\mathrm{it}}+\beta_{2} \mathrm{LTD}_{\mathrm{it}}+\beta_{3} \mathrm{LAR}_{\mathrm{it}}+\varepsilon_{\mathrm{it}} \\
& \mathrm{ROA}_{\mathrm{it}}=-0.024-0.036+\mathrm{NDIA}_{\mathrm{it}}+0.05 / \mathrm{LID}_{\mathrm{it}}+0.052+\mathrm{LAR}_{\mathrm{it}}+\varepsilon_{\mathrm{it}} \\
& \text { Interpretation }
\end{aligned}
$$

From the result in Table 4.2.2, the significant value of F-Stat/ Wald (P-value $)=12.87(0.005)$ is shows that the model is fit. In other words, it means that the combine effect of liquidity risks proxies (Net Debt to Total Asset (NDTA), Loan to Deposit Ratio (LTD) and Liquid Asset Ratio (LAR)) on Return on Asset (ROA) is statistically significant at 5\% level of significance. Correspondingly, the $\boldsymbol{A d j} . \boldsymbol{R}^{2}=0.118$ further confirmed the fitness of the model by showing that the explanatory variables jointly accounts for about $11.8 \%$ of variation in the Return on Asset.

Based on the coefficient of Net Debt to Total Asset (NDTA), the result shows that the coefficient of the variable is negative but not statistically significant at $5 \%$ level of significance (coeff. $=-0.036 ; \mathrm{P}-$ value $=0.226$ ). This means that the effect of Net Debt to Total Asset (NDTA) on the performance (based on Return on Asset) of Deposit Money Banks in Nigeria during the period of this study is negative and not significant. All the same, it can be seen that the coefficient of Loan to Deposit Ratio (LTD) is positive and statistically significant at 5\% level (coeff. $=0.057 ; \mathrm{p}-$ value $=0.022$. In other words, it posits that Loan to Deposit Ratio (LTD) has positive and significant effect on the performance (based on Return on Asset) of Deposit Money Banks in Nigeria. This relationship is similar to the one found between Loan to Deposit Ratio (LTD) and Return on Equity (ROE) in the preceding Table. Correspondingly, this implies that a unit increase in Loan to Deposit Ratio (LTD) of the selected listed banks in Nigeria during the period of this study improves Return on Asset (ROA) of the banks by about 0.057 units. Just as Loan to Deposit Ratio (LTD), the effect of Liquid Asset Ratio (LAR) is seen to be positive and statistically significant at $1 \%$ level (coeff. $=0.052 ; \mathrm{p}-$ value $=0.010)$. This means that Liquid Asset Ratio (LAR) has positive and significant effect on the performance (based on Return on Asset) of Deposit Money Banks listed in Nigeria. Besides, the significant result suggests that Return on Asset (ROA) of the Deposit Money Banks in Nigeria during the period of this study increased by 0.052 units given a unit increase in Liquid Asset Ratio (LAR). Decision: Based on the result of the regression analysis, the statistical evidence from $F$-Stat $/$ Wald $(P$-value $)=$ 12.87 (0.005); Adj. $\mathrm{R}^{2}=0.118$ found support for the rejection of the null hypothesis two $\left(\mathrm{H}_{02}\right)$ which states that Liquidity risk has no significant effect on return on equity of Deposit Money Banks listed in Nigeria. As a result, the study concludes that Liquidity risk has significant effect on return on equity of Deposit Money Banks listed in Nigeria.

Hypothesis Three

Research Hypothesis (Ho3): Liquidity risk has no significant effect on earnings per share of Deposit Money Banks in Nigeria. 
Table 4.2.3: Regression Result for Earnings per Share

\begin{tabular}{|c|c|c|c|c|}
\hline \multirow{3}{*}{ Variable } & \multicolumn{4}{|c|}{ Random-effects GLS regression with Driscoll-Kraay standard errors } \\
\hline & \multicolumn{4}{|c|}{ EPS is the Dependent Variable } \\
\hline & Coeff. & $\begin{array}{l}\text { Drisc/Kraay Std. } \\
\text { Err. }\end{array}$ & t-Stat. & Prob. \\
\hline NDTA & -4.284 & 3.285 & -1.300 & 0.225 \\
\hline LTD & $4.365 * *$ & 1.655 & 2.640 & 0.027 \\
\hline LAR & $4.747 * *$ & 2.004 & 2.370 & 0.040 \\
\hline cons & -1.158 & 0.880 & -1.320 & 0.221 \\
\hline Model Fitness Test & \multicolumn{4}{|c|}{ F-Stat $/$ Wald $(P$-value $)=20.92(0.000) ;$ Adj. $\boldsymbol{R}^{2}=0.080$} \\
\hline \multirow{2}{*}{ Panel Effect Tests } & \multicolumn{4}{|c|}{ Hausman Test $($ P-value $)=3.54(0.316)$} \\
\hline & \multicolumn{4}{|c|}{ LM Test $(P$-value $)=3.33(0.045)$} \\
\hline \multirow{3}{*}{ Post-Estimation Tests } & \multicolumn{4}{|c|}{ PCD test $(P$-value $)=5.627(0.000)$} \\
\hline & \multicolumn{4}{|c|}{$\begin{array}{c}\text { Heteroskedasticity Test }(\text { P-value })=27.92(0.000) \\
\text { Serial-Auto Correlation Test }(\boldsymbol{P} \text {-value })=1.543(0.232)\end{array}$} \\
\hline & \multicolumn{4}{|c|}{ Serial-Auto Correlation Test $($ P-value $)=1.543(0.232)$} \\
\hline
\end{tabular}

Source: Authors' Computation, 2020. Note: ***, ** represent $1 \%$ and $5 \%$ levels of significance.

Model Selection: Hausman Tests and Breusch and Pagan LM Test

Again, the result in Table 4.2.3 suggests the acceptance of the null hypothesis which states that the difference in coefficients are not systematic since the Hausman Test $(\mathrm{P}$-value $)=3.54(0.316)$ appears to be insignificant at $5 \%$ level of significance. This means that the result is in favour of Random Effect (RE) estimators. In view of that, RE is found to be a suitable model for investigating the effect of liquidity risk on financial performance (based on Earnings per Share) of Deposit Money Banks listed in Nigeria. Additionally, the Breusch and Pagan LM Test result further support the decision to use RE model and confirms that the RE model is good in this subsection since the LM Test $(\mathrm{P}$-value $)=3.33(0.045)$ is significant (Panel effect exists) at 5\% level.

Heteroskedasticity Test, Serial Autocorrelation Test and Cross Sectional Dependence Test

Pesaran CD test statistic results in Table 4.2.3 was employed to confirm whether the estimated model has cross sectional dependence problem or not when we are examining the effect of Net Debt to Total Asset (NDTA), Loan to Deposit Ratio (LTD) and Liquid Asset Ratio (LAR) on Earnings per Share (EPS). As in the Table (Table 4.2.3), the PCD test value was statistically significant PCD test $(\mathrm{P}$-value $)=5.627(0.000)$. This recommends that the null hypothesis of no problem of cross sectional dependence in the model should be rejected, thus concludes that the model is not free form cross sectional dependence problem. Likewise, the test statistic values for heteroskedasticity test Heteroskedasticity Test $(\mathrm{P}$-value $)=27.92(0.000)$ is statistically significant at $5 \%$ level. This recommends that the null hypothesis of homoscedasticity should be rejected. For these reasons, the study used Random-effects GLS regression with Driscoll-Kraay standard errors that is robust to the possibility of cross sectional dependence and heteroskedasticity problems. In contrast, the serial autocorrelation test carried out to check whether the relationship between the residual of the models and its lagged version over various time intervals correlate, shows an insignificant Serial-Auto Correlation Test $(\mathrm{P}$-value $)=1.543(0.232)$ which indicated the absence of first order autocorrelation among the series in the model.

The estimated fixed effect model is stated as follows:

$$
\begin{aligned}
& \text { EPS }_{i t}=\beta_{0}+\beta_{1} \text { NDTA }_{i t}+\beta_{2} \text { LTD }_{i t}+\beta_{3} \mathrm{LAR}_{i t}+\varepsilon_{i t} \\
& \text { EPS }_{i t}=-1.158-4.284 * \mathrm{NDTA}_{i t}+4.365 * \mathrm{LTD}_{\mathrm{it}}+4.747 * \mathrm{LAR}_{\mathrm{it}}+\varepsilon_{\mathrm{it}}
\end{aligned}
$$

Interpretation

Again, the result in Table 4.2.3 show a significant F-Stat / Wald (P-value) $=20.92(0.000)$ value which is indicated that the model is fit. In other words, it meant that the overall effect of liquidity risks indicators (Net Debt to Total Asset (NDTA), Loan to Deposit Ratio (LTD) and Liquid Asset Ratio (LAR)) on Earnings per Share (EPS) was statistically significant at $5 \%$ level of significance. Consistently, the Adj. $\mathrm{R}^{2}=0.080$ further confirmed the fitness of the model by showing that the explanatory variables jointly explain about $8.0 \%$ of variation in the Earnings per Share.

The coefficient of Net Debt to Total Asset (NDTA) in the result shows a negative and statistically insignificant result at $5 \%$ level of significance (coeff. $=-4.284$; $p-$ value $=0.225$ ). This meant that the effect of Net Debt to Total Asset (NDTA) on the performance (based on Earnings per Share) of Deposit Money Banks listed in Nigeria during the period of this study was not significant just as with ROE and ROA models. All the same, it can be seen that the coefficient of Loan to Deposit Ratio (LTD) is positive and statistically significant at 5\% level (coeff. = $4.365 ; \mathrm{p}-$ value $=0.027$. In other words, it demonstrates that Loan to Deposit Ratio (LTD) has positive and 
significant effect on the performance (based on Earnings per Share) of Deposit Money Banks in Nigeria. This relationship is similar to the one found between Loan to Deposit Ratio (LTD) and other performance indicators considered in this study. Correspondingly, this meant that a unit increase in Loan to Deposit Ratio (LTD) of the selected banks listed in Nigeria during the period of this study improved Earnings per Share (EPS) of the banks by about 4.365 units. Just as Loan to Deposit Ratio (LTD), the effect of Liquid Asset Ratio (LAR) is seen to be positive and statistically significant at $5 \%$ level (coeff. $=4.747 ; \mathrm{P}-$ value $=0.040$ ). This means that, Liquid Asset Ratio (LAR) has positive and significant effect on the performance (based on Earnings per Share) of Deposit Money Banks listed in Nigeria. Besides, the significant result suggests that Earnings per Share (EPS) of the Deposit Money Banks listed in Nigeria during the period of this study increase by 4.747 units given a unit increase in Liquid Asset Ratio (LAR).

Decision: Based on the result of the regression analysis, the statistical evidence from F-Stat $/$ Wald $(\mathrm{P}$-value $)=$ $20.92(0.000)$; Adj. $\mathrm{R}^{2}=0.080$ found support for the rejection of the null hypothesis $\left(\mathrm{H}_{02}\right)$ which states that Liquidity risk has no significant effect on earnings per share of Deposit Money listed in Nigeria. As a result, the study concluded that Liquidity risk has significant effect on earnings per share of Deposit Money Banks listed in Nigeria.

\subsection{Conclusion}

This research study underpins or supports with evidence the fact that there exists a strong positive relationship among loan to deposit ratio, liquid asset ratio and banking profitability in terms of return on assets, return on equity and earning per share. While net debt to total asset observed an inverse but insignificant effect on banks' profitability. Therefore, the need for efficient liquidity management in the banking industry cannot be overemphasized particularly for reasons of maximizing profit levels and concurrently remaining liquid. For the banking industry in Nigeria, there is the need to emphasize 'the need to remain liquid'. The study concluded that efficient liquidity management can significantly influence returns on banks' earning per share as well as impact positively on the banks' profitability and thus its stability.

\subsection{Recommendations}

Below are the recommendations of the study:

i. Management of deposit money banks should put in place appropriate and sustainable policy which lays emphasis on compliance measures to check high volume idle in the bid to meet with liquidity requirements except to the extent of liquidity requirements which was noticeable in the banks studied. This is important because liquidity management is key to the profitability of banks since there should be a careful mix between profitability and liquidity.

ii. Management of deposit money banks should institute mechanism to check and monitor all the nonperforming loans in order to reduce the occurrence of non-performing loans and bad debts which negatively affects profitability, hence, capital bases. Banks without adequate capital is a potential danger to the entire financial system since such can trigger systemic distress

iii. Management of deposit money banks should use credit risk management strategies to complement liquidity management in order to reduce the incidence of non-performing loans in deposit money banks listed in Nigeria.

\section{References}

Bordeleau, E., \& Graham, C. (2010). The impact of liquidity on bank profitability. 4-22.

Bosede, A. F., Olusegun, O., \& Olubukunola, U. (2013). Return on investment of deposit money banks (DMBs) in Nigeria. Journal of Applied Finance \& Banking.

Edem, D. B. (2017). Liquidity management and performance of deposit money banks in Nigeria (1986 - 2011): An Investigation. International Journal of Economics, Finance and Management Sciences, 5(3), 146-161.

Eljelli M. A. (2004). Liquidity-profitability tradeoff: An empirical investigation in emerging market. International Journal of Management

Elliott, D. J. (2014). Bank liquidity requirements: An introduction and overview. 1-30.

García-Cicco, J., \& Kawamura, E. (2014). Central bank liquidity management and "Unconventional" Monetary Policies. Economia Journal of the Latin American and Caribbean Economic Association, 15, 37-87.

Heikal, M., Khaddafi, M., \& Ummah, A. (2014). Influence Analysis of Return on Assets (ROA), Return on Equity (ROE), Net Profit Margin (NPM), Debt To Equity Ratio (DER), and current ratio (CR), Against Corporate Profit Growth In Automotive In Indonesia Stock Exchange. International Journal of Academic Research in Business and Social Sciences.

Ibe, S. O. (2013). The impact of liquidity management on the profitability of banks in Nigeria. Journal of Finance and Bank Management, 37-48.

Jenkinson, N. (2008). "Strengthening regimes for controlling liquidity risk", Euro Money 
Conference on Liquidity and Funding Risk Management, Bank of England, London.

Kashif, M., Khan, R., \& Syed, N. (2013). Liquidity Risk and Performance of the Banking System.

Koch, W., \& Scott, S. (2009). Bank Management .

Kumar, M., \& Yadav, G. C. (2013). Liquidity Risk Management in Bank: A Conceptual Framework. AIMA Journal of Management and Research, 7(2), 2-12.

Luckett, G. (1984). Money and Banking.

Maaka, Z. A. (2013). The Relationship Between Liquidity Risk and Financial Performance of Commercial Banks in Kenya. 1-49.

Machiraju, H. (2008). Modern Commercial Banking. New Age International.

Nwaezeaku, N. C. (2006). Theories and Practice of Financial Management.Owerri. Ever Standard Publishing.

Ogbulu, O. M., \& Eze, G. P. (2016). Credit Risk Management and the Performance of Deposit Money Banks in Nigeria. An Error Correction Analysis, 97.

Olusegun, O. \& Olubukunola, U. (2013). The Effects of Company Income Tax on Dividend Policy of Firms in Nigeria, EconPapers, 9(1), 79-90

Siaw, S. (2013). Liquidity risk and bank profitability in Ghana. 1-105.

Tabari, N. A., Ahmadi, M., \& Emami, M. (2013). The effect of liquidity risk on the performance of commercial banks. International Research Journal of Applied and Basic Sciences, 4(6), 1624-1631.

Tesfaye, T. (2012). Determinants of banks liquidity and their impact on financial performance: empirical study on commercial banks in Ethiopia.

Varotto, S. (2011). Liquidity risk, credit risk, market risk and bank capital. International Journal of Managerial Finance, 7, 134-152.

Waleed, A., \& Ahmed Tisman Pasha, A. A. (2018). Exploring the impact of liquidity on profitability: Evidence from banking sector of Pakistan. Journal of internet Banking Commerce.

Yusuf, M. A. (2015). Theories of banking. 